Heitor Pons Leite, Simone Brasil de Oliveira Iglesias,

Cacilda Maria de Santana Faria, Angela Maria Ikeda, Maria Paula de Albuquerque, Werther Brunow de Carvalho

\title{
Evolution of the nutritional support pattern in pediatric intensive care
}

\author{
Pediatric Intensive Care Unit of Department of Pediatrics, Escola Paulista de Medicina, \\ Universidade Federal de São Paulo - São Paulo, Brazil
}

\begin{abstract}
Objectives: to evaluate patterns of usage and monitoring of nutritional support in a Pediatric ICU of a teaching hospital and the role of an education program in nutritional support given throughout the resident physician training. Design: in a historical cohort study, records from children who received nutritional support during the year 1992 were analyzed. Thereafter a continuing education program in Nutritional Support was conveyed to the residents. In a second phase of the study, the same parameters were reevaluated in children who received nutritional support throughout the year 1995. Setting: Pediatric Intensive Care Unit of Department of Pediatrics, Escola Paulista de Medicina. Patients: all the children who were given nutritional support during a period of five days or more. Based on this criteria 37 children were selected for the first phase of this study, and 35 for the second one. Intervention: the education program included theoretical lectures about basic themes of nutritional support and journal article reading sessions. It was given to successive groups of residents on a weekly schedule. Measurements: Daily records of fluid, protein, caloric and micronutrient supply, nutritional assessment and metabolic monitoring. Results: In the first phase of the study, an exclusively parenteral route was utilized for $80.5 \%$, and a digestive route $19.5 \%$ of the time period. Nutritional assessment was performed on 3 children; no patient had the nutritional goals set. The nitrogen to nonprotein calories ratio and the vitamin supply were inadequate, whilst the supply of trace elements was adequate except for zinc. Nutritional monitoring was performed on almost all patients but without uniformity. In the second phase, the exclusive parenteral route was used for $69.7 \%$ and the digestive route for $30.3 \%$ of the time period; no significant increase in the use of the digestive route was detected. The nonprotein calories to nitrogen ratio and micronutrient supply were adequate. The frequency of nutritional assessment increased, but deficiency in nutritional monitoring and infrequent enteral feeding were still detected. Conclusion: There were deficiencies in the implementation of nutritional support, which were partially corrected in the second phase of the study by the training of the residents. Reinforcement of the education program, which should be applied to the whole medical staff, and the organization of a multidisciplinary team in charge of coordinating the provision of nutritional support are suggested.
\end{abstract}

UNITERMS: Nutritional support. Intravenous Hyperalimentation. Enteral Feeding. Nutritional assessment.

\section{INTRODUCTION}

$\mathrm{N}$ utritional support has increasingly gained importance in treatment and prognosis of patients admitted into hospital due to severe illness ${ }^{(1)}$.

\author{
Address for correspondence: \\ Heitor Pons Leite \\ Rua Artur Figueiredo, 11 \\ São Paulo/SP - Brasil - CEP 04012-150
}

The development of new parenteral and enteral nutrition techniques has improved perspectives of these patients by reducing in-hospital morbidity. Since it is a relatively recent treatment, most hospitals do not have a team organized exclusively for this purpose. Considering the high prevalence of malnutrition in children admitted into Pediatric ICU ${ }^{(2)}$ and the risk of aggravating the picture by hypercatabolism caused by illness, it is extremely relevant to implement appropriate nutritional support for these patients. Few studies in the literature have conducted 
a critical approach to this subject ${ }^{(3,4,5,6)}$. Although presenting different casuistry, all studies reported important problems in implementing nutritional support. This study was designed to evaluate patterns of usage and monitoring of nutritional support in a Pediatric Intensive Care Unit and the role of a program for continuous education in nutritional support given to residents of the ICU.

\section{PATIENTS AND METHODS}

In a historical cohort study, children admitted into the Pediatric Intensive Care Unit of São Paulo Hospital, Escola Paulista de Medicina, who received nutritional support during the year 1993 were analyzed. After the first phase of this study a course of continuous education in nutritional support was given to successive groups of residents of the third year. The course was given weekly and each session lasted about sixty minutes. It at first included theoretical lectures about basic themes of nutritional support and throughout the school year it included journal article reading sessions where recent and original papers about nutritional support in critically ill patients were presented. In a second phase of the study which was carried out in 1996, the same parameters were reevaluated in children who received nutritional support throughout the year 1995 .

\section{Table 1}

\section{Patients according to the diagnosis in the two} phases of the study

\begin{tabular}{lrrr}
\hline Diagnosis & Phase I & Phase II & \multicolumn{1}{c}{ Total (\%) } \\
\hline Cardiac Surgery & 11 & 13 & $24(33.3 \%)$ \\
Sepsis & 8 & 9 & $17(23.6 \%)$ \\
Pneumonia & 8 & 2 & $10(13.9 \%)$ \\
Neurosurgery & 4 & 3 & $7(9.7 \%)$ \\
Epileptic & 2 & 2 & $4(5.5 \%)$ \\
Renal Failure & 1 & 3 & $4(5.5 \%)$ \\
Encephalitis & 1 & 1 & $2(2.8 \%)$ \\
Miscellaneous & 2 & 2 & $4(5.5 \%)$ \\
\hline Total & 37 & 35 & 72 \\
\hline
\end{tabular}

\section{PATIENTS}

The criteria adopted for the inclusion of patients in the study was nutritional support administration during a period of five days or more. Based on this criteria thirtyseven children were selected for the first phase of this study, and thirty-five for the second one. There was no significant difference in the age group of the patients between the two phases of the study, with median values of 10 months ( 1 to 120) in the first phase, and 9 months ( 1 to 144 months) in the second phase. Table 1 shows the main diagnosis of the patients when admitted into ICU, in both phases of the study.

\section{NUTRITIONAL SUPPORT}

Nutritional support is given to every child admitted into the unit, as of the moment they are hydrated and are in hemodynamic stability, initially given by the parenteral route. Parenteral nutrition is administered when enteral access cannot be obtained, when enteral nutrition support fails to meet nutritional requirements, and when feeding into the gastrointestinal tract is contraindicated. In this unit it is mainly used for acute illness leading to metabolic stress and as nutritional support in post-operative care. Solutions with glucose concentration up to $12.5 \%$ are administered by peripheral vein, and those which contain higher concentrations are infused via central vein. Solutions are administered with lipid emulsions mixed in the same vial. When the digestive route can not be used (presence of ileum, digestive hemorrhage or abdominal distention) the nasoduodenal route is associated to the parenteral. A blender diet is used, prepared by the Hospital Dietetic and Nutritional Service, with a modified formula with no lactose and enriched with casein and dextrinmaltose, caloric contents $1 \mathrm{kcal} / \mathrm{ml}$, nitrogen to nonprotein calorics ratio 1:100, and osmolarity $289 \mathrm{mOsm} / \mathrm{L}$. We use polyurethane tubes and administer diet continuously by infusion pumps. Post-pyloric tube placement is confirmed by abdominal $\mathrm{x}$-ray and is monitored daily by $\mathrm{pH}$ dosage of withdrawn fluid. The oral route is used in children with no need for respiratory support, and blender diet or modified milk is introduced. 


\section{METHODS}

Daily records of fluid, protein, caloric and micronutrients supply, initial nutritional assessment and monitoring were evaluated during treatment. To assess caloric supply received by patients, the rule of Holliday \& Segar ${ }^{(7)}$ was taken into consideration. As for protein supply, nitrogen to nonprotein calorics ratio equal to or greater than 1:100 was considered appropriate ${ }^{(8)}$. Vitamin and trace element supply by the parenteral route was compared with the recommendations of the American Society for Clinical Nutrition ${ }^{(9)}$. In order to characterize the nutritional support monitoring, the following parameters were considered: record of protein-caloric supply, fluid balance, weight, and laboratory tests: hemogram, gasometry, serum urea, glycemia, sodium, potassium, calcium, albumin and triglycerides. Assessment of nutritional status was considered whenever there was reference to nutritional status in the case notes.

\section{STATISTICAL ANALYSIS}

Statistical analysis was performed using the MannWhitney test to compare the differences in time period for the use of nutritional support, as well as time periods for enteral nutrition and ages of patients, in both phases of the study. Fisher's exact test was used to compare the exclusive parenteral route and digestive route in relation to full supply of the estimated caloric needs. In all tests the level for rejection of the equality hypothesis was established at 0.05 or $5 \%$.

\section{RESULTS}

In both phases of the study, the nutritional support was initiated within 48 hours of admission. In the first phase, from a total of 425 days of nutritional support, the exclusive parenteral route was used for 342 days $(80.5 \%$ of the total nutritional support period) and the digestive route (tube feeding or oral route) for 83 days $(19.5 \%)$. In the second phase, from a total of 403 days of nutritional support the exclusive parenteral route was used for 281 days $(69.7 \%)$ and the digestive route for 122 days (30.3 $\%)$. There was no difference in the time periods of nutritional support in the two phases of the study $(\mathrm{z}=$ 0.23 ) and there was no significant increase in use of the digestive route in the second phase $(z=1.84)$. In the first phase, $29.7 \%$ of the patients had their caloric need supplied and the nitrogen to nonprotein calorie ratio ranged from 1:250 to 1:80. In the second phase, $28.6 \%$ of the patients had their caloric needs supplied and the nitrogen to nonprotein calorie ratio ranged from 1:150 to 1:100. Table 2 shows comparative data of adequacy of nutritional support observed in the two phases of the study. The full estimated caloric need supply was achieved only in children who received nutrition by the digestive route - a significant association between use of enteral route and the full estimated caloric need supply was observed in the two phases of the study ( $\mathrm{p}=0.0160$ and $\mathrm{p}=0.0086$, respectively). Tables 3 and 4 , respectively, show patients in phases I and II according to the caloric supply and administration route for nutritional support.

Nutritional monitoring included weight, serum albumin and triglycerides and was performed in most patients, although with no uniformity. Table 5 shows

\section{Table 2}

Patients according to the nutrient supply in the two phases of the study

\begin{tabular}{lcc}
\hline & Phase I & Phase II \\
\hline $\begin{array}{l}\text { Energy supply } \\
100 \mathrm{kcal} / \mathrm{kg} / \mathrm{d}\end{array}$ & $11(29.7 \%)$ & $10(28.6 \%)$ \\
$\begin{array}{l}\mathrm{N}_{2}: \text { non } \\
\text { protein calories }\end{array}$ & $10(27 \%)$ & $35(100 \%)$ \\
$\begin{array}{l}\text { Trace elements } \\
\text { Vitamins }\end{array}$ & $\begin{array}{c}\text { Inadequate for zinc } \\
\text { Lacking in biotin, folate, } \\
\text { B12, inadequate for A, D }\end{array}$ & Adequate \\
& Adequate
\end{tabular}

Table 3

Phase I patients according to the energy supply and the route of nutrition support administration

\begin{tabular}{ccc}
\hline $\begin{array}{c}\text { Energy Goal } \\
\text { Achieved }\end{array}$ & $\begin{array}{c}\text { Exclusive } \\
\text { Parenteral }\end{array}$ & $\begin{array}{c}\text { Enteral } \\
\text { Associated }\end{array}$ \\
\hline Yes & 0 & $10^{\star}$ \\
No & 16 & 21 \\
\hline Total & 16 & 31 \\
\hline
\end{tabular}

${ }^{*}$ Fisher Exact Test $-\mathrm{P}=0.016$ 


\section{Table 4}

Phase II patients according to the energy supply and the route of nutrition support administration

\begin{tabular}{ccc}
\hline $\begin{array}{c}\text { Energy Goal } \\
\text { Achieved }\end{array}$ & $\begin{array}{c}\text { Exclusive } \\
\text { Parenteral }\end{array}$ & $\begin{array}{c}\text { Enteral } \\
\text { Associated }\end{array}$ \\
\hline Yes & 0 & $9^{\star}$ \\
No & 12 & 14 \\
\hline Total & 12 & 23 \\
\hline
\end{tabular}

${ }^{*}$ Fisher Exact Test $-\mathrm{P}=0.0086$

comparative data for nutritional support monitoring in this and other studies in the literature.

\section{DISCUSSION}

The nutritional and metabolic profile of critically ill patients is different from that observed in patients in nutritional deprivation. This has led to the development of a new treatment approach called metabolic support ${ }^{(8)}$, which aims at maintenance of organic structure and of optimal conditions for recovery of injured tissues and for immunologic defense. This approach differs from the traditional, since it is aimed at critically ill patients with increased nutrient needs, but who, on the other hand, present limitations in the acute phase of the process regarding manipulation of substrates and fluid volume. Current guidelines for nutritional support including practice standards for the critically ill child have recently been published ${ }^{(10)}$.

In our study, less than a third of the patients received all estimated caloric needs and the majority of the patients did not receive even half of them. The factors that may limit the administration of caloric supply are: need for fluid restriction, which is often required in critically ill patients, and infrequent use of the enteral route. In fact, in both phases of the study, the patients who could receive all estimated caloric needs were those for whom the digestive route was used, indicating the need for use together with enteral nutrition in order to attain an adequate caloric supply, or to provide a greater caloric supply to patients in parenteral nutrition by peripheral veins ${ }^{(11)}$.

An important advance in understanding the role of enteral nutrition in critically ill patients has taken place. The absence of nutrients in the digestive tube may be harmful since it needs low-level nutrient exposure to maintain its trophism and baseline functional status. Experience has shown that enteral nutrition initiated earlier, and administered with correct techniques and appropriate diets, is a safe and effective method for administering nutritional support (11). However, it is important to mention that success in enteral nutrition is directly related to awareness and motivation of physicians and to continuous monitoring and care by nursing staff. Although limited in several clinical conditions, the use of the oral route for nutritional support is more physiological, less expensive and results in fewer complications, and it should be always considered when the patient is conscious and his gastrointestinal tract is in good condition ${ }^{(12,13)}$.

Planas ${ }^{(6)}$, in a study of nutritional support patterns in 27 Intensive Care Units, observed that enteral nutrition was used in $59.7 \%$ of the patients (adults) who received nutritional support. Ioannides et al. ${ }^{(3)}$, through an audit carried out in a teaching hospital in Australia, observed that parenteral nutrition was prescribed to patients with the gastrointestinal tract in good condition and receiving food by mouth. Despite the advantages of the use of enteral nutrition, parenteral nutrition has been generally been adopted as the nutritional treatment for critically ill patients, particularly children. In practice, technical and material

Table 5

Nutrition support monitoring - Comparative data

\begin{tabular}{lcccc}
\hline & $\begin{array}{c}\text { McFarlane et al. } \\
(1991)\end{array}$ & $\begin{array}{c}\text { loannides et al. } \\
(1995)\end{array}$ & $\begin{array}{c}\text { Leite et al. } \\
\text { Phase I }\end{array}$ & $\begin{array}{c}\text { Leite et al. } \\
\text { Phase II }\end{array}$ \\
\hline $\begin{array}{l}\text { № Patients } \\
\text { Route }\end{array}$ & 20 Children & 168 Adults & 37 Children & 35 Children \\
Nutritional Assessment & Parenteral & Parenteral & Parenteral/ Enteral & Parenteral/ Enteral \\
Triglycerides Monitoring & $3(15 \%)$ & $168(100 \%)$ & $3(8 \%)$ & $13(37.1 \%)$ \\
\hline
\end{tabular}


difficulties and presence of complications such as ileum and digestive hemorrhage may delay or prevent the use of enteral nutrition. These factors, associated with the fact that physicians are not aware of the advantages of the use of the digestive route, may account for the low use of enteral nutrition. In our study, the increase in use of the digestive route was not significant in the second phase, indicating that enteral nutrition continues to be little used.

The analysis of the results of this study points to the urgent need for revision of the evaluation of function and use of the gastrointestinal tract in critically ill patients, as well as the evaluation of practical methods of tube positioning in the duodenum and jejunum.

In hypercatabolic children, protein supply basically aims at minimizing the effects of loss of nitrogen, partially compensating hypercatabolism. In this situation the main purpose of nutrient supply is not growth, but maintenance of corporeal mass and organic function in order to provide the conditions for the patient to survive. For this purpose, an increase in aminoacid supply is recommended, using a nitrogen to non-protein calorie ratio from 1:150 to 1:100 ${ }^{(8,14,15)}$, greater than that commonly used for children with no metabolic stress. In the first phase of the study, and considering that virtually all the patients were hypercatabolic, this ratio was appropriate in only $27 \%$ of the cases, rising to $100 \%$ during the second phase.

The prescription of insufficient doses of vitamins and trace elements in solutions for parenteral nutrition observed during the first phase of this study was also reported by McFarlane et al. ${ }^{(4)}$ in their study. In the first phase of our study, zinc supply by the parenteral route was inadequate because it was based only on corporeal weight, not taking into account age group. Ideally, the recommendations from the American Society for Clinical Nutrition ${ }^{(9)}$ should be adopted, classifying the need for zinc according to age group and gestational age. The need for vitamins and trace elements should be enhanced, since there is a greater probability of deficiency due to increase in use and losses that occur in hypercatabolism. In this situation, the needs are greater but have not yet been determined. If there are previous deficiencies or greater losses, the early use of trace element solution is desirable.

In the presence of cholestasis, copper and manganese must not be administered, because they present hepatic excretion ${ }^{(9)}$. Vitamin B12, folate and zinc are imperative for the normal metabolism of nucleic acids. Zinc deficiency affects wound healing, protein synthesis in the acute phase response and immunological function. Since zinc is more used and more excreted in hypercatabolism, and its supply is more flexible than that of other trace elements, it is recommended that it is administered in separate solutions. For adequate supply, vitamins must be administered in specific formulae for pediatric use.
Daily supply monitoring and periodic evaluation of nutritional and metabolic status are necessary for adequate supply of nutritional support. Data must be registered regularly on the daily evolution sheet, in order to enable correct assessment and introduction of necessary changes.

In the current study and in that of McFarlane et al. (4) the initial evaluation of nutritional status was carried out with a very small number of patients. In the study by Ioannides et al. ${ }^{(3)}$, conducted with adults, all patients were submitted to a previous nutritional evaluation, since this procedure was part of the audit performed by the nutritional support multidisciplinary team. Checking patients' weight, as is normally done, does not mean nutritional evaluation; to this end, it is necessary to use a reference standard such as that of the World Health Organization ${ }^{(16)}$. The parameter expected weight for age is useful up to the age of 2 , but from then on, it is only valid as a screening for evaluation of nutritional status. Height must also be taken into account, because from ratios of expected height for age and expected weight for height, it is possible to evaluate the duration of a malnutrition process ${ }^{(17)}$. It is important to highlight that all parameters used for nutritional evaluation are influenced by non-nutritional factors such as changes in body fluids, inflammation and infection ${ }^{(1,18)}$. These parameters have very little value when used separately, and should be sequentially evaluated, having the patient as his own control. Nutritional reassessment at regular intervals allows the efficiency of metabolic support and intolerance to administration of nutrients to be checked, and makes changes in nutritional support possible according to the evolution of the patient. Irregular laboratory monitoring was also observed by McFarlane et al. ${ }^{(4)}$. In his reasoning, although all children received intravenous lipid emulsions, less than half of them had serum triglyceride measured at least once, a result similar to that found in the present study. It is important to monitor serum triglyceride in critically ill children receiving intravenous lipid emulsions, because in this situation, there may be a decrease in lipid clearance, leading to deposits in the vascular endothelium and reticuloendothelial system. Monitoring must be performed before beginning infusion, and whenever there is an increase in lipid supply, maintaining levels under $150 \mathrm{mg} / \mathrm{dl}$. Serum albumin alone is not a good parameter for assessing nutritional status or nutritional support in a Pediatric Intensive Care Unit, since it may vary according to inflammatory response, presence of infection and changes in the corporeal fluids. Nevertheless, it is a good evolution parameter, being useful in predicting morbidity and mortality in critically ill patients ${ }^{(19)}$. 
In our study, fluid balance and caloric supply record were performed daily for all children. Hemograms and blood gas analysis were conducted for all patients, as well as serum glucose, urea and electrolytes. Fluid balance, weight and accurate quantifying of nutrient administration are essential clinical parameters, principally for patients receiving parenteral nutrition. Checking of corporeal weight and albumin and triglycerides dosages was carried out on the majority of patients while admitted into hospital, although the procedures were not uniform.

In the two phases of this study nutritional support was initiated early. This reflects perception of the increase in metabolic needs of patients by the ICU physician. Early beginning of nutritional support is an important issue in the treatment of critically ill children. Patients with severe illness, and who were healthy before, may tolerate hypercatabolism during a few days with no great adverse effects. The metabolic demands are greater in those who, in addition to the acute process, suffer from chronic disease, are in a fast stage of growth or suffer from malnutrition.

\section{CONCLUSION}

Nutritional support presented failures during its implementation that were partially corrected during the second phase of the study. The guidance work increased awareness of the use of nutritional support, but did not foster effective changes in practical procedures performed by residents. Based on the results of this study, the authors recommend:

1) Review of the education program. A basic approach, designed for practical problems in nutritional support and oriented to correct deficiencies observed, may be able to correct these deficiencies and contribute better to the training of ICU pediatricians regarding this aspect. The program should be applied to the whole medical staff.

2) Creation of a multidisciplinary team in charge of coordinating supply of nutritional support. Studies of the literature have demonstrated that the performance of a multidisciplinary team may promote substantial improvement in quality of nutritional support ${ }^{(20)}$. The team will be responsible for quality and for adjustment of nutritional support, and must establish procedure guidelines that are periodically revised and updated. These actions may rationalize the supply of nutritional and metabolic support, adjusting it to the needs of the patient and enhancing the quality of care rendered to children.

\section{Resumo}

Objetivos: avaliar o padrāo terapêutico e de monitoração do suporte nutricional em uma UTI Pediátrica de um hospital escola, e o papel de um programa de educação continuada em suporte nutricional ministrado aos residentes. Desenho: em estudo de coorte histórico foram inicialmente estudadas crianças internadas durante o ano de 1992 que receberam suporte nutricional. Seguiu-se a esta avaliação um programa de educação continuada nesta área, administrado para os residentes da unidade. Em uma segunda fase do estudo os mesmos parâmetros foram reavaliados nas crianças que receberam suporte nutricional durante o ano de 1995. Local: UTI Pediátrica do Hospital São Paulo - Departamento de Pediatria da Escola Paulista de Medicina. Participantes: Todos as crianças que receberam suporte nutricional por um tempo igual ou superior a 5 dias perfazendo um total de 37 crianças na primeira fase e 35 crianças na segunda fase do estudo. Intervenção: Curso de educação continuada, ministrado semanalmente e constituido por aulas teóricas e leitura de artigos de revista sobre suporte nutricional. Mensuração: Foram analisados os registros diários de oferta hídrica, protéico-energética e de micronutrientes, de avaliaçäo nutricional e de monitoração do suporte nutricional no decorrer da terapêutica. Resultados: na primeira etapa do estudo via parenteral exclusiva foi utilizada em $80,5 \%$ do tempo e a via digestiva em $19,5 \%$. A avaliação nutricional prévia foi feita em 3 pacientes $(8,1 \%)$. A relação nitrogênio:calorias não protéicas e a oferta de vitaminas foram inadequadas e a oferta de oligoelementos por via parenteral foi adequada, exceçāo feita ao zinco. A monitoração nutricional foi efetuada na maior parte dos pacientes, embora de modo não uniforme. Na segunda fase, a via parenteral exclusiva foi utilizada em $69,7 \%$ e a via digestiva em $30,3 \%$, não se observando diferença significante entre as duas fases. A avaliação nutricional prévia foi feita em 13 pacientes $(37,1 \%)$, A relação nitrogênio:calorias não protéicas e a oferta de micronutrientes foram adequadas mas permaneceram as deficiências de monitoração nutricional e metabólica e o uso pouco freqüente da nutriçāo enteral. Conclusões: 0 suporte nutricional apresentou falhas na implementaçāo que foram parcialmente corrigidas na segunda etapa do estudo. Sugere-se a reformulação do programa de educação continuada, a sua extensão à totalidade do corpo clínico e a criaçāo de uma equipe multidisciplinar encarregada de coordenar o fornecimento de suporte nutricional. 


\section{REFERENCES}

1. Chwals WJ. Metabolism and nutritional frontiers in Pediatric surgical patients. Surg Clin North Am 1992; 72(6): 1237-1266.

2. Leite HP, Isatugo MKI, Sawaki L, Fisberg M. Anthropometric Nutritional Assessment of Critically IIl Hospitalized Children. Rev Paul Med 1993; 111(1):309-13.

3. Ioannides-Demos LL, Liolios L, Topliss DJ, Mclean A. A prospective audit of total parenteral nutrition at a major teaching hospital. Med J Autralia 1995;163:233-37.

4. McFarlane K, Bullock L, Fitzgerald JF. A Usage Evaluation of Total Parenteral Nutrition in Pediatric Patients. JPEN 1991;15(1):85-88.

5. Payne-James JJ, de Gara CJ, Grimble GK, Bray MJ, Rana SK, Kapadia S, Silk DBA. Artificial nutrition support in hospitals in the United Kingdom - 1991: Second national survey. Clin Nutr 1991;11:187-192.

6. Planas M. Artificial nutrition support in intensive care units in Spain. Int Care Med 1995;21:842-46.

7. Holliday MA, Segar WE. The maintenance need for water in parenteral fluid therapy. Pediatrics 1957; 19:823-832.

8. Cerra FB. Hypermetabolism, organ failure and metabolic support. Surgery 1987;101(1):1-13.

9. Greene HL, Hambidge K, Schanler R, Tsang RC. Guidelines for the use of vitamins, trace elements, calcium, magnesium and phosphorus in infants and children receiving total parenteral nutrition: Report of the Subcommittee on Clinical Practice Issues of the American Society for Clinical Nutrition. Am J Clin Nutr 1988;48:1324-42.
10. A.S.P.E.N. Board of Directors. Guidelines for the use of Parenteral and Enteral Nutrition in Adult and Pediatric Patients. JPEN 1993;17(4):1SA-52SA.

11. Leite HP, Carvalho WB, Grandini S. Nasoduodenal feeding of the critically ill child. Rev Paul Med 1992;10(3):124-30.

12. HESSOV I. Oral diet administration and supplementation. In: Artificial Nutrition Support in Clinical Practice. PayneJames J, Grimble G, Silk G. (eds) Edward Arnold, London, 1995;573.

13. Telles JR M, Tannuri U. Suporte Nutricional em Pediatria. Atheneu, S.P., 1994;315.

14. Diamand RJ. Nutritional support of the critically ill infant and child. In: Pediatric Review Series - Part 2. Stidham GL, Weigle CGM. (ed) Society of Critical Care Medicine, Anaheim, CA, 1993;172.

15. Mateos AGL, Culebras JM. Nutritional and metabolic support: Converging concepts. Nutrition 1991;7:163-167.

16. Organizacion Mundial De La Salud - Medición del Cambio del Estado Nutricional. Ginebra, OMS, 1983;105.

17. Waterlow JC. Classification and definition of protein-calorie malnutrition. Br Med J 1972;3:566-69.

18. Leite HP. Avaliaçāo do estado nutricional e indicadores de risco cirúrgico em crianças submetidas à cirurgia cardíaca. São Paulo, 1992. [Master's Thesis - Escola Paulista de Medicina].

19. Apelgren KN, Rombeau JL, Twomey PL, Miller RA. Comparison of nutritional indices and outcome in critically ill patients. Crit Care Med 1982;10(5):305-307.

20. Burnham WR. The role of a nutrition support team. In: Artificial Nutrition Support in Clinical Practice. PayneJames J, Grimble G, Silk G. (eds) Edward Arnold, London, $1995 ; 573$. 